ZESZYTY NAUKOWE UNIWERSYTETU SZCZECIŃSKIEGO

NR 890

EKONOMICZNE PROBLEMY USŁUG NR 120

2015

DOI: 10.18276/epu.2015.120-09

\author{
Anna Tomová* \\ Ivana Kirschnerová**
}

\title{
NETWORK STRATEGIES OF EUROPEAN LOW COST AND HYBRID(IZED) AIRLINES: IS RYANAIR UNIQUE? ${ }^{1}$
}

\begin{abstract}
Summary
The paper analyses network strategies of eleven European low cost and hybrid(ized) airlines between 2009 and 2014 focusing on spatial (geographical) attributes. Two-dimensional description of airline network evolution identified three of four possible spatial network strategies which were followed by the airlines - expansion, contraction and condensation; revealing expansion as a prevailing one. Ryanair as an expanding airline increased transnational nature of its network (confirmed by geographical spread indices), however out of the EEA region Ryanair expanded least within the expanding airlines. Against the compared expanding counterparts, the only Ryanair increased exploitation of its network connectivity potential. Ryanair had the lowest levels of network concentration what coincides with an assumption about deconcentrated network typical for pure (ultra) low cost carrier. Our findings support the statement that economies generated by spatial connectivity of airline networks play a crucial role in competition of airlines as their business is in principle spatially determined.
\end{abstract}

* Doc. Ing. Anna Tomová, CSc., Faculty of Operation and Economics of Transport and Communications, University of Žilina, Univerzitná 1, 01026 Žilina, the Slovak Republic, anna. tomova@fpedas.uniza.sk.

** Ing. Ivana Kirschnerová, Faculty of Operation and Economics of Transport and Communications, University of Žilina, Univerzitná 1, 01026 Žilina, the Slovak Republic, ivana.kirschnerova@fpedas.uniza.sk.

1 Supported by KEGA 024 ŽU-4/2014 grant scheme. 
Keywords: airlines, network, strategy, connectivity, concentration, geographical spread, economies of scale

JEL classification: L2, L93

\section{Introduction}

In 2001, only North America accounted double-digit market share of low cost carriers. In 2010, historically for the first time, all world regions (Middle East as well) acquired double-digit results of this indicator, showing Europe as a leader in this respect with value $35.3 \% .^{2}$ Low cost carriers delivering a new business model(s) within the airline industry has increased supply of air services on many origin - destination markets what resulted on sharpened competition of airlines.

Competitive features of low cost carriers and hybrid(ized) carriers (i.e. carriers somewhere between pure low cost and full service network carriers) has been already analysed. As airlines business is in principle of spatial nature ${ }^{3}$ competitiveness of airlines is impacted by the level of exploitation of economies of scale and economies of density. While economies of scale are stemming from the number of airports within airline networks, routes within networks indicate how potential of spatial connectivity given by the number of airports is exploited. On the other hand, routes within networks can be exploited differently in time showing temporal exploitation of spatial connectivity given by airline's routes inbuilt within its network. ${ }^{4}$ Spatial connectivity in synergy with temporal connectivity generated by network and traffic design are thus sources for economies of scale and economies of density and they are important in competitiveness of airlines.

This paper investigates how networks of eleven European low cost and hybrid(ized) airlines spatially evoluted comparing the spatial parameters of their networks in 2009 and 2014 years. We used two-dimensional description of network evolution based on changes in the number of airports within the networks and changes in the number of countries belonging to the networks in

2 European Commission, 2013. Annual Analysis of the EU Air Transport Market, 2011, http://ec.europa.eu/transport/modes/air/internal_market/observatory_market/doc/annual-2011summary.pdf

3 P. Belobaba et al., 2009. The Global Airline Industry. Wiltshire: John Wiley \& Sons.

4 Temporal configuration of European airline networks between 1990-1999 was researched by Burghouwt and de Wit [10]. 
time. Thus, we identified four possible geographical (spatial) network strategies - expansion, replacement, contraction and condensation in two geographical scopes. Subsequently, we applied quantitative ratios aimed at geographical spread of airline network over countries (geographical spread indices), spatial connectivity of network and concentration of network. While geographical spread index has not been used so far in this context, gamma and beta connectivity indices and concentration index as well are standard tools in the research of networks. We did not consider in this analysis tempral dimension of airline networks which predetermines economies stemmed from temporal connectivity. Thus, only spatial attributes of networks have been revealed in this paper.

\section{Research on spatial attributes of European airline network}

Airlines networks were investigated in several studies. Bourghouwt et al. ${ }^{5}$ researched how the spatial dimensions of European airlines networks changed between 1990 and 1999. They predicted network expansion of European low cost carriers in Europe, mainly Ryanair at the European continent and lower levels of its network concentration in future. Dobruskesz identified geographical expansion of European low cost carriers due to liberalisation and integration of European market. ${ }^{6}$ In his further paper, Dobruszkes revealed different typology of European low cost carrier networks and proved the expansion of European low cost carriers out of European market since 2004. ${ }^{7}$ Dynamics in the network evolution of European low cost carriers due to the enlargement of the European Union was documented by Dudas. ${ }^{8}$ Reynolds-Ferighan examined the pattern of airline network development covering North America and Europe regions and the most important carriers in these regions between 1996-2008. ${ }^{9}$ Ryanair and easyJet included in this analysis were denoted as carriers with the relatively higher

5 G. Burghouwt et al., 2003. The spatial configuration of airline networks in Europe. Journal of Air Transport Management 9, 309-323.

6 F. Dobruszkes, 2006. An analysis of European low-cost airlines and their networks. Journal of Transport Geography 14, 249-264.

7 F. Dobruszkes, 2013. The geography of European low-cost airline networks: a contemporary analysis. Journal of Transport Geography 28, 75-88.

8 G. Dudas, 2010. Low Cost Airlines in Europe: Network Structure after the Enlargement of the European Union. Geographica Pannonica 14/2, 49-58.

9 A.J. Reynolds-Ferighan, 2010. Characterisation of airline networks: a North American and European Comparison. Journal of Air Transport Management 16, 109-120. 
level of network interconnectedness against full service network carriers. Reggiani et al. analysed Lufthansa network development and emphasized importance of network configuration for competitiveness of airlines in a competitive environment under liberalized market conditions. ${ }^{10}$ Similarly, Müller et al. analyzing network strategy of JetBlue tied the success and sustainability of airline business strategy with the decisions to spread the business spatially. ${ }^{11}$ Also the OECD study on airline competition stated geographical coverage of airline network, size and other spatial network attributes as important for competition of airlines. ${ }^{12}$

\section{Data and choice of airlines}

Applying four types of quantitative ratios, we investigated network evolution of eleven European passenger airlines which belong to the most important low cost or hybrid(ized) European airlines between 2009 and 2014. Ryanair, Norwegian, Blue Air, Vueling, EasyJet, Flybe, Germanwings, Jet2, Transavia and Wizz Air are listed as low cost carriers in line with the ICAO definition of low cost carriers. ${ }^{13}$ According to Klophaus et al. even only Ryanair, Wizz Air and Blue Air within the analysed group of airlines may be identified as pure low cost carriers and that is why the rest of the analysed airlines in this paper can be labelled as hybrid or hybridized. ${ }^{14}$ To perform the analysis we built a set of the data for a representative March week in 2014 year exploiting the internet sites of the airlines. The data collection followed the procedure of Dudas who provided us with the respective representative week 2009 year dataset. ${ }^{15}$ The common rules of gathering the data with Dudas enabled to evaluate the changes in quantitative network indicators of the airlines between 2009 and 2014 and develop a new

10 A. Reggiani et al., 2011. Connectivity and Concentration in Airline Networks: A Complexity Analysis of Lufthansa's Network. TI 2011-111/3 Tinbergen Institute Discussion Paper.

11 K. Müller et al., 2012. The Construction of a Low Cost Airline Network: Facing competition and exploring new markets. ZEW Discussion Paper No. 11-052. http://ftp.zew.de/pub/zewdocs/dp/dp11052.pdf.

12 OECD, 2014. Airline Competition. Background Paper by the Secretariat. DAF/ $\operatorname{COMP}(2014 / 14)$.

13 ICAO, 2014. List of LCC based on ICAO definition. www.icao.int/sustainability/Documents/LCC-List.pdf.

14 R. Klophaus et al., 2012. Low cost carriers going hybrid: Evidence from Europe. Journal of Air Transport Management 23, 54-58.

15 G. Dudas, 2010. Low Cost Airlines in Europe: Network Structure after the Enlargement of the European Union. Geographica Pannonica 14/2, 49-58. 
typology capable to distinguish among eleven analysed European hybrid(ized) and low cost airlines according to spatial strategies of their networks. ${ }^{16}$ Moreover, to achieve a broader benchmarking of the 2014 results and cover the industry more we subsequently computed the 2014 network ratios for Air Berlin+Niki, ${ }^{17}$ Air Baltic and Meridiana Fly. These three airlines were denoted by Klophaus et al. as full service carriers although such strict demarkation based on a composed quantitative index need not to be generally accepted or at least can be objected. ${ }^{18}$ For instance, Meridiana Fly is still considered by ICAO as a low cost carrier ${ }^{19}$ and Air Baltic has been identified as a hybrid carrier by Huettinger ${ }^{20}$ and also Vidovic et al. ${ }^{21}$

\section{Methodology}

The focus of the analysis was on geographical and spatial characteristic of the airlines networks. Therefore, we started with two-dimensional description based on changes in the number of airports within the networks and changes in the number of countries belonging to the networks in time. Such approach enabled to define four airlines network spatial (geographical) strategies according to two scale parameters - number of airports and number of countries.

To reveal a transnational level of the airlines network we used two variants of geographical spread indices. Geographical Spread Index $(G S I)^{22}$ is based on

16 G. Dudas, 2010. Low Cost Airlines in Europe: Network Structure after the Enlargement of the European Union. Geographica Pannonica 14/2, 49-58.

17 Niki and Air Berlin were analysed as a whole. NIKI strengthened ties with airberlin, which increased its interest in Niki Lauda's Austrian carrier from 24 percent to 49.9 percent in 2010. Air Berlin has been a member of the ONEWORLD Alliance since 20th March 2012. The Austrian airline NIKI, which is a member of the airberlin group, is now an affiliate member of the alliance.

18 R. Klophaus et al., 2012. Low cost carriers going hybrid: Evidence from Europe. Journal of Air Transport Management 23, 54-58.

19 ICAO, 2014. List of LCC based on ICAO definition. www.icao.int/sustainability/Documents/LCC-List.pdf.

20 M. Huettinger, 2006. Air Baltic and SAS - a case study in the European airline industry. Baltic Journal of Management, Vol. 1 Iss: 2, pp. 227-244.

21 A. Vidovic et al., 2013. Development of Business Models of Low Cost Airlines. International Journal of Traffic and Transportation Engineering 3 (1), 69-81.

22 Geographical Spread Index is a standard analytical tool developed within UNCTAD for transnational corporation activities. Our approach is a specific application of GSI and our applicative innovation in the airline networks context [22]. 
Internationalization Index $(I I)$ and a number of foreign countries $\left(n_{c}\right)$ served by an airline's operation. Internalization index is a share of foreign airports within the network of an airline in the total number of airports within the network.

$$
G S I=\sqrt{I I \cdot n_{c}} .
$$

We used Geographical Spread Indices in two variants - GSI and $G S I_{2}$. The first variant of the index considers any country out of home country in which an airline is registered as a foreign one. The second variant coincides more with the common rules for the operation of air services in the European Economic Area (EEA) as given by the Regulation 1008/2008 establishing common rules for the operation of air services in the Community. Therefore, in the second variant of GSI any country out of the EEA is regarded as a foreign country and the region of EEA represents a single domestic market with air services. ${ }^{23}$ Geographical spread indices are capable to measure the intensity of transnational nature of airlines network, the changes of the phenomenon in time due to organic growth of networks or growth resulted from mergers and acquisitions of airlines (mergering and/or acquiring networks, too) .

Gamma index measures the level of connectivity within the network comparing a number of operated routes $(e)$ - edges between vertexes in the network in both directions) within airports in the network with the maximum possible one $\left(v^{2}-v\right)$ determined by the number of airports within the network $(v) .{ }^{24} \mathrm{We}$ used Gamma index as a characteristics enabling to express spatial exploitation of network connectivity potential.

$$
\gamma=\frac{e}{v^{2}-v}
$$

Beta index expresses an average number of operated outbounding O-D routes $\left(e_{o}\right)$, within the network from an airport:

$$
\beta=\frac{e_{o}}{v} .
$$

23 We kept the geographical scale of the EEA in our analyses in its 2014 dimensions to achieve the same, i.e. comparable geographical coverage.

24 We did not include in our analysis code-share connections if operated by partner's carrier to avoid double-counting. Any transfer connection has been decomposed to partial O-D connections. 
Our approach to Beta index did not regard a number of operated flights, only a number of connections (edges within network) in the airline's supply. Under these assumptions, Beta index may be interpreted as an average number of connections in the airline's offer outbounding from an airport within the airline's network. This variant of Beta index reveals the spatial scale of operated connections and did not reveal time dimensions in the airline routes supply expressed for instance by the number of operated flights on the routes or seats etc. This approach was fully in line with our investigation aimed just at the spatial characteristics of airlines network.

Concentration ratio $(\mathrm{CR})$ represents a share of the most important airports $\left(s_{i}\right)$ in the total operation of an airline within its network:

$$
C R=\sum_{i=1}^{3} s_{i}
$$

We worked in our analysis with three most important airports expressing the shares through a number of operated O-D routes $(e)$ from and to airports within the network. This approach enables to investigate importance of airports in an airline's operation, however, use of different data (frequencies, seats supplied etc.) would naturally give different results. The results of CRs may support (or contradict) an idea about a more deconcentrated network of airlines belonging to low cost or hybrid(ized) business model. 


\begin{tabular}{|c|c|c|c|c|c|c|c|c|c|c|c|c|c|c|c|}
\hline \multirow{2}{*}{ 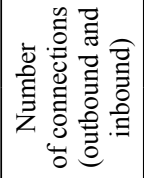 } & 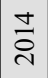 & 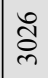 & 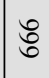 & กิ & 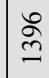 & $\stackrel{\mathscr{H}}{\mathscr{f}}$ & 啄 & $\frac{0}{6}$ & $\stackrel{\infty}{-}$ & $\tilde{\sigma}$ & 六 & $\tilde{n}$ & $\underset{\infty}{\infty}$ & $\cong$ & $\stackrel{\Xi}{=}$ \\
\hline & ڤ્̀ે & ల్ర & $\stackrel{\infty}{\sim}$ & \& & $\stackrel{\infty}{\circ}$ & $\stackrel{\circ}{\sim}$ & $\sigma$ & $\stackrel{\infty}{=}$ & $\stackrel{0}{I}$ & $\begin{array}{l}\infty \\
0 \\
ల\end{array}$ & $\underset{\sim}{\sim}$ & $\underset{\mathcal{F}}{\stackrel{\mathcal{T}}{\sim}}$ & $\stackrel{\underset{\oplus}{\sharp}}{ }$ & $\stackrel{\oplus}{\dot{g}}$ & $\stackrel{\underset{\oplus}{=}}{ }$ \\
\hline \multirow{2}{*}{ 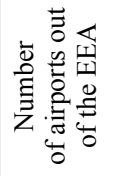 } & 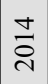 & 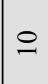 & $=$ & 0 & $\stackrel{\sim}{ }$ & $\nabla$ & ¿ & $\approx$ & $\circ$ & $\cong$ & - & $\vec{\sim}$ & $\stackrel{\sim}{\sim}$ & \pm & $r$ \\
\hline & 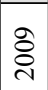 & 6 & $\sigma$ & 0 & $=$ & $\nabla$ & $\simeq$ & $\nabla$ & N & $r$ & N & $\cong$ & 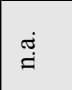 & 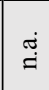 & ঙேं \\
\hline \multirow{2}{*}{ 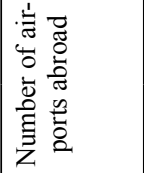 } & $\stackrel{\nabla}{\stackrel{\sim}{\sim}}$ & $\stackrel{\infty}{-}$ & $\approx$ & $\infty$ & $\stackrel{\Xi}{త}$ & $\stackrel{\infty}{+}$ & $\curvearrowleft$ & $\hat{\sigma}$ & $\approx$ & $\stackrel{\Xi}{\Xi}$ & $\stackrel{g}{f}$ & হ & $\hat{a}$ & in & $I$ \\
\hline & ڤ્ণ & ले & $\stackrel{\infty}{+}$ & $\hat{\sim}$ & t & $\vec{\nabla}$ & 6 & $\stackrel{\sim}{\sim}$ & $n$ & ชิ & లి & $\stackrel{i}{\circ}$ & 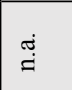 & $\stackrel{\overbrace{}}{\dot{I}}$ & 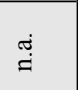 \\
\hline \multirow{2}{*}{ 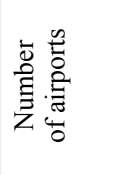 } & $\stackrel{\nabla}{\vec{\sim}}$ & $\stackrel{\infty}{\infty}$ & $\hat{a}$ & $\vec{\sim}$ & $\ddot{g}$ & in & a & $\stackrel{m}{=}$ & g) & $\tilde{\Xi}$ & $\infty$ & $\stackrel{\infty}{=}$ & ปี & in & లె \\
\hline & ஓें & $\stackrel{n}{ \pm}$ & in & mे & $\stackrel{\ominus}{\varrho}$ & $\stackrel{\infty}{+}$ & $\infty$ & 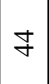 & in & $\dddot{n}$ & $\stackrel{\circ}{n}$ & 8 & 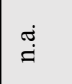 & $\stackrel{\text { İ }}{=}$ & $\stackrel{\overbrace{}]}{\operatorname{d}}$ \\
\hline \multirow{2}{*}{ 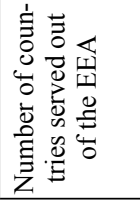 } & $\stackrel{\nabla}{\stackrel{\Delta}{*}}$ & $m$ & $\simeq$ & 0 & $a$ & $m$ & $\circ$ & $\simeq$ & in & 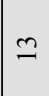 & - & $=$ & $\stackrel{0}{0}$ & $a$ & $r$ \\
\hline & ஓे & $\sim$ & 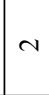 & 0 & $\nabla$ & $\nabla$ & in & $\mathrm{N}$ & - & 6 & - & $a$ & 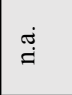 & $\stackrel{\text { İ }}{=}$ & 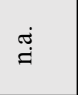 \\
\hline \multirow{2}{*}{ 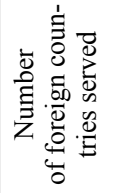 } & $\stackrel{\nabla}{\stackrel{\sim}{*}}$ & $\stackrel{\infty}{\sim}$ & $m$ & $\infty$ & $m$ & $\beth$ & i & $\tilde{m}$ & $\tilde{N}$ & $\infty$ & \pm & i্ & $m$ & $\tilde{m}$ & $a$ \\
\hline & ठ্ণ & $\approx$ & $\infty$ & $ㅇ$ & $\stackrel{\sim}{\sim}$ & 2 & $\because$ & 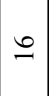 & 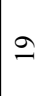 & $\dddot{\sim}$ & $=$ & $\dddot{\sim}$ & 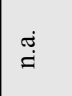 & $\stackrel{\text { I }}{=}$ & ঙேं \\
\hline \multirow{2}{*}{ 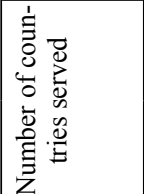 } & $\stackrel{ \pm}{\vec{N}}$ & ते & mे & $a$ & $\stackrel{+}{m}$ & $\infty$ & $\hat{\sim}$ & ల & $\ddot{\sim}$ & m) & 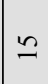 & $\bar{m}$ & $\tilde{m}$ & r & $ㅇ$ \\
\hline & 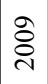 & $\stackrel{\sim}{\sim}$ & 9 & $=$ & $\hat{\sim}$ & 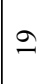 & 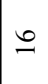 & $=$ & $\stackrel{\sim}{~}$ & i & $\cong$ & i & $\stackrel{\mathscr{I}}{=}$ & $\stackrel{\overbrace ্}{\dot{I}}$ & ঙேं \\
\hline \multicolumn{2}{|l|}{ 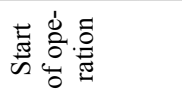 } & $\stackrel{\mathscr{\alpha}}{\circ}$ & ڤ્ণ & 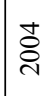 & ڤ̆ & ช్ & ¿ & 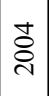 & 吕 & $\tilde{\Omega}$ & §̊ & 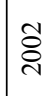 & 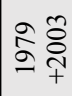 & ڤ̆ & むু \\
\hline \multirow[t]{2}{*}{ 总意 } & & 뙴 & 总 & $\begin{array}{l}\Sigma \\
0 \\
\approx\end{array}$ & 光 & $\breve{s}$ & 受 & $\begin{array}{l}\hat{\tilde{n}} \\
\text { II }\end{array}$ & 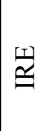 & 咅 & $\breve{s}$ & 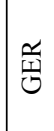 & 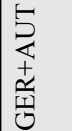 & 安 & 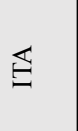 \\
\hline & & 离 & 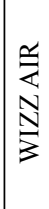 & 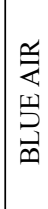 & 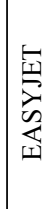 & $\stackrel{v}{\underline{\omega}}$ & 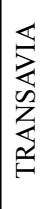 & 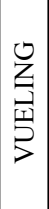 & 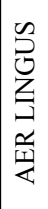 & 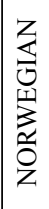 & 䆓 & 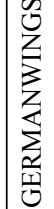 & 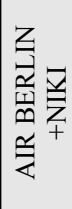 & 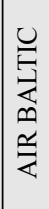 & 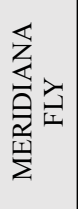 \\
\hline
\end{tabular}




\section{Results}

The results obtained are gathered in Table 2 .

Table 2. Spatial Attributes of Airline Networks 2009 and 2014

\begin{tabular}{|c|c|c|c|c|c|c|c|c|c|c|}
\hline \multirow[t]{2}{*}{ Airline } & \multicolumn{2}{|c|}{$\mathrm{GSI}_{1}$} & \multicolumn{2}{|c|}{$\mathrm{GSI}_{2}$} & \multicolumn{2}{|c|}{$\begin{array}{l}\text { Gamma Index } \\
\text { in } \%\end{array}$} & \multicolumn{2}{|c|}{ Beta Index } & \multicolumn{2}{|c|}{$\begin{array}{l}\text { Concentration } \\
\text { Index } \\
\text { (three airports) }\end{array}$} \\
\hline & 2009 & 2014 & 2009 & 2014 & 2009 & 2014 & 2009 & 2014 & 2009 & 2014 \\
\hline Ryanair & 4.90 & 5.22 & 0.29 & 0.40 & 7.8 & 8.8 & 5.64 & 8.13 & 0.29 & 0.20 \\
\hline Wizz Air & 4.08 & 5.68 & 0.39 & 1.45 & 10.8 & 7.2 & 2.75 & 3.43 & 0.35 & 0.28 \\
\hline Blue Air & 2.81 & 2.62 & 0.00 & 0.00 & 8.0 & 12.4 & 1.32 & 1.24 & 0.67 & 0.90 \\
\hline easyJet & 4.71 & 5.33 & 0.63 & 1.14 & 7.4 & 7.3 & 4.05 & 5.02 & 0.36 & 0.31 \\
\hline Jet2 & 4.02 & 3.78 & 0.57 & 0.46 & 9.3 & 13.3 & 2.19 & 3.74 & 0.69 & 0.56 \\
\hline Transavia & 3.79 & 4.99 & 0.93 & 1.42 & 4.2 & 4.1 & 1.41 & 2.03 & 0.79 & 0.70 \\
\hline Vueling & 3.07 & 5.76 & 0.43 & 1.56 & 9.4 & 4.8 & 2.02 & 2.70 & 0.70 & 0.61 \\
\hline Aer Lingus & 4.21 & 4.55 & 0.18 & 0.85 & 5.2 & 3.8 & 1.49 & 1.30 & 0.91 & 0.94 \\
\hline Norwegian & 4.55 & 5.67 & 0.74 & 1.42 & 6.6 & 4.3 & 2.45 & 2.65 & 0.60 & 0.57 \\
\hline Flybe & 2.43 & 2.84 & 0.19 & 0.10 & 10.5 & 5.2 & 2.89 & 2.18 & 0.53 & 0.43 \\
\hline Germanwings & 4.61 & 5.02 & 1.33 & 1.40 & 5.6 & 3.9 & 1.83 & 2.25 & 0.92 & 0.62 \\
\hline Air Berlin+ Niki & - & 5.12 & - & 1.85 & - & 5.6 & - & 3.39 & - & 0.45 \\
\hline Air Baltic & - & 5.86 & - & 1.49 & - & 3.5 & - & 0.98 & - & $\begin{array}{l}1.00 \\
\text { (one } \\
\text { airport } \\
\text { only) }\end{array}$ \\
\hline Meridiana fly & - & 2.19 & - & 1.23 & - & 11.5 & - & 1.78 & - & 0.60 \\
\hline
\end{tabular}

Source: own study.

\subsection{Predominantly expanding network strategy}

Based on the two-dimensional framework working with changes in number of airports and number of countries within the airlines networks we identified the following spatial network strategies of airlines: 


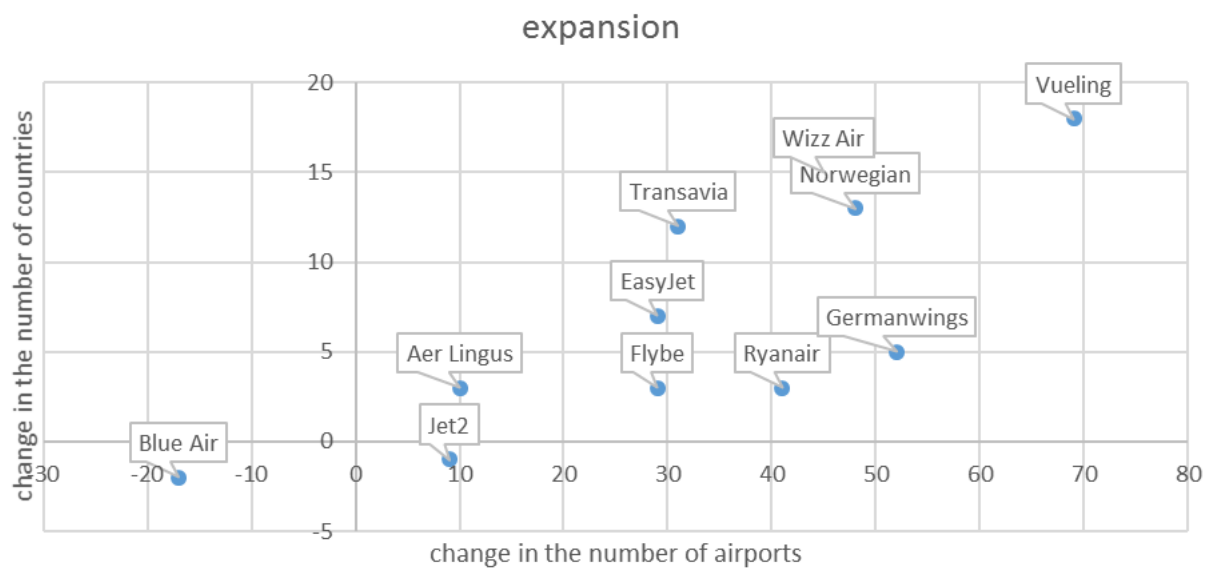

Figure 1. Geographical (Spatial) Strategies of Airline Networks 2009/2014 Source: own study.

- Strategy of network expansion both in a number of airports and countries served,

- strategy of network contraction both in a number of airports and countries served,

- strategy of condensation meaning decrease in a number of countries concurrently with increase in a number of airports served by an airline's operation,

- strategy of replacement meaning decrease in a number of airports in parallel with increase in a number of countries served by an airline's operation.

Since 2009 to 2014, nine of eleven analysed European hybrid(ized) and low cost airlines ${ }^{25}$ expanded geographically capturing more countries and airports served by their operation. Within the airlines, Vueling was the most expanding airline acording to both parameters increasing in the number of airports by 69 and the number of countries by 19 . The only network contraction was recorded by Blue Air. On the other hand, Jet 2 contracted slightly its network in the number of countries but expanded in the number of airports served what resulted in geographically more condensed spatial network in 2014 compared with 2009. It brings an evidence about prevailing strategies of network geographical

25 We did not include in this aprt of the analysis 2009 Meridiana Fly, Air Baltic, Air Berlin + Niki not disposing by necessary data. 
(spatial) expansion followed by the business of analysed European low cost and hybrid(ized) airlines between 2009 and 2014.

To document geographical expansion of the airlines' network out of the EEA we applied the above mentioned procedure according to both considered parameters, however out of the EEA. Hence, the EEA region is considered as a single geographical space for European carriers operation within domestic, i.e. intra-European market. Geographical expansion of the airlines out of the EAA region can then be interpreted as the expansion over foreign markets.

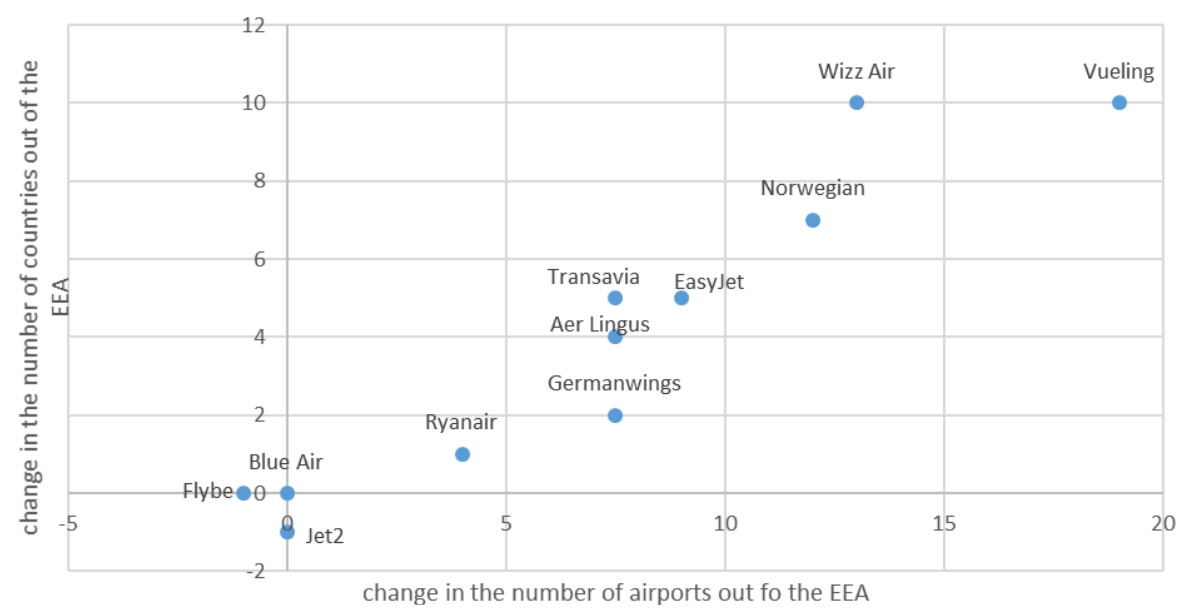

Figure 2. Geographical (Spatial) Strategies of Airline Networks 2009/2014 out of the EEA

Source: own study.

Contrary to the previous results, eight airlines expanded within the analysed period out of the EEA and out of the EEA, Vueling was again the most expanding airline within the analysed group. Similarly, Wizz Air recorded the same expansion out of the EEA region according to the number of countries as Vueling, however not so much as Vueling according to the increase in the number of airports. Jet2 reduced the number of countries out of the EEA by one but keeping the number of airports served the same. Jet2 positioned itself between strategy of contraction and condensation with regard to the movement of its network out of the EEA region. Flybe which was included among the expanding airlines within the previous spatial scope of the analysis decreased slightly the number of 
airports out of the EEA while keeping the number of countries out of the EEA the same. Thus, Flybe positioned itself between strategies of replacement and contraction. Within the analysed group the only Blue Air had no operation out of the EEA in both analysed years. The analysis revealed a uniquacy of Ryanair's spatial (geographical) network strategy. Within the group of expanding airlines Ryanair's expanded its network out of the EEA region, however least of the rest of expanding low cost and hybrid(ized) airlines.

\subsection{Predominantly increased transnational scope of networks}

In bulk, due to geographical expansion over countries and airports, expanding European hybrid(ized) and low cost carriers increased transnational nature of their networks (and consequently operation) between 2009 and 2014 which was confirmed by increased values of GSI for all expanded nine airlines. While in 2009 Ryanair's network was the most transnationalized within eleven compared European low cost and hybrid(ized) airlines achieving GSI score 4.90, in 2014, due to a more intensive geographical expansion, Vueling, Wizz Air, Norwegian, easyJet recorded a higher levels of transnationalisation of their networks expressed by GSI in comparison with Ryanair. Moreover, Ryanair with still a relatively high GSI 1 score 5.22 in 2014 recorded the value of GSI $_{2} 0.40$ - the third lowest value of $\mathrm{GSI}_{2}$ within the group of eleven airlines. This shows a unique position of Ryanair in its network geographical (spatial) expansion which is intensive transnationally but less intensive out of the EEA region confronting it with the rest of expanding airlines. The results of Ryanair with regard to its geographical spatial network characteristics together with the results for the rest of airlines raises a question about (possible) crowding out (at least some) of Ryanair's European low cost and hybrid(ized) competitors out of the EEA region.

\subsection{Potential of network connectivity differently exploited}

Within the airlines which recorded spatial expansion of their networks between 2009 and 2014, the only Ryanair's increased exploitation of its network connectivity potential confirmed by an increased value of Ryanair's Gamma index in 2014. By other words, due to improved spatial connectivity of Ryanair's 
network, source for economies of spatial connectivity was inbuilt in the Ryanair's network strategy. Moreover, the Ryanair's value of Beta index was the highest one in 2014 counting 8.13 far away of the rest of eleven airlines starting with the second highest value 5.02 of EasyJet. Even adding Air Berlin + Niki, Air Baltic and Meridiany Fly, Ryanair came to stay as a leader in Beta index value in 2014. The majority of expanding airlines (with exception of Aer Lingus) also recorded increased levels of Beta index on their networks but in spite of adding routes at expanding networks they recorded decreased exploitation of network connectivity potential expressed by Gama index. Aer Lingus as an expanding airline decreased both Gama and Beta indices in the analysed period. Blue Air following a strategy of network contraction decreased Beta index while increased Gama index. Jet2 following a strategy of network condensation recorded increased values of both connectivity indices. The only Ryanair's among the rest of expanding airlines was able to increase exploitation of its network connectivity potential by adding sufficient number of routes within its expanding network between 2009 and 2014.

\subsection{Largely more deconcentrated networks}

Within analysed expanding airlines only Aer Lingus increased concentration of its network (based on the most important three airports in network). The rest of expanding airlines as well as Jet2 with a strategy of network condensation decreased concentration of its network. Ryanair and Wizz Air recorded the lowest levels of network concentration in both years (0.29 in 2009 and 0.20 in 2014 for Ryanair; 0.35 in 2009 and 0.28 in 2014 for Wizz Air). In both years, Ryanair's results of spatial network concentration are the lowest ones what is fully with an assumption about lower levels of network concentration due to point to point operation typical for pure low cost carriers. In this context, the values of concentration indices for Ryanair and Wizz Air confirm demarkation of both airlines as the purest low cost as it was stated by typology of airline business models designed by Klophaus et al. ${ }^{26}$ However, the values of concentration indices obtained

26 R. Klophaus et al., 2012. Low cost carriers going hybrid: Evidence from Europe. Journal of Air Transport Management 23, 54-58. 
for the rest of airlines did not confirm unambiguously allocation of the airlines according to the designed types of business models as made by Klophaus et al. ${ }^{27}$

\section{Conclusions}

Networks strategies and spatial evolution of networks in time play a crucial role in the business of airlines which is in principle of a spatial nature as business of airlines is performed on networks of routes. Stemming from the paper results, we split eleven European hybrid(ized) and low cost carriers according to the common spatial attributes in the evolution of their networks between 2009 and 2014 in this manner:

- Ryanair - an expanding network internationally and out of the EEA region but not so intensively, improved spatial exploitation of the connectivity potential, network more deconcentrated, the lowest concentration of network among the airlines analysed.

- Wizz Air, easyJet, Transavia, Vueling, Norwegian, Germanwings - expanding network internationally and out of the EEA region, added more routes within the networks however spatial exploitation of the connectivity potential decreased, network more deconcentrated.

- Aer Lingus - an expanding network internationally and out of the EEA, spatial exploitation of the connectivity potential decreased, average number of routes per airport decreased, network more concentrated.

- Flybe - an expanding network internationally, decreased number of airports out of the EEA, decreased spatial exploitation of the connectivity potential, average number of routes per airport decreased, network more deconcentrated.

- Jet2 - an condensing network internationally, decreased number of countries served out of the EEA, spatial exploitation of the connectivity potential increased, average number of routes per airport increased, network more deconcentrated.

27 It fully supports a challenge raised by Nair et al. [15]: In order to provide a more coherent and consistent understanding of airline management and strategy, we need a comparative approach ... Literature survey reveals lack of quantitative tools and methods to analyze business models. Comparative analysis of airline networks according to business models has been so far made by Scholz [16]: for three business models of cargo carriers. Also our results show that nor traditional approach distinguishing low cost and full service network models nor newer ones introduced by Klophaus et al. [12] do not describe the industry sufficiently. 
- Blue Air - a contracting network internationally, no network points out of the EEA, spatial exploitation of network increased, average number of routes decreased, network more concentrated.

Analyses of airlines networks evolution we performed using eleven European important low cost and hybrid(ized) airlines brought as a main research output a uniquacy of Ryanair's network strategy and unique spatial evolution of its network against the counterparts. The results pointed out the Ryanair's exeptionality as the Ryanair's network expanded transnationally although not so intensively out of the EEA region in comparison with the rest of expanding low cost and hybrid(ized) European airlines. Within the group of expanding airlines, the only Ryanair has increased spatial exploitation of its growing network connectivity potential between 2009 and 2014. According to the number of airports, Ryanair was ranked as a leader within the analysed group in both year (139 in 2009, 181 in 2014), i.e. the highest potential for economies of scale and density on its network. The Ryanair results of Beta index (meaning average routes per airport) were the highest in both years, even far off the rest of airlines confirming that Ryanair increased sufficiently number of routes on expanding network (and the largest within the group of analysed airlines) to achieve better spatial exploitation of the network connectivity potential in time. Jet 2 was revealed by our analysis as the airline following a strategy of condensation with increased spatial exploitation of its network connectivity potential. This confirms that there are different spatial network strategies enabling to improve exploitation of network potential spatially. Similarly, also contracting Blue Air improved spatial exploitation of its network connectivity potential. In this connection one cannot exclude that airlines may follow such strategy of network evolution which is not so intensively exploited spatially but better exploited in time (adding frequencies, seats etc.). Undoubtly, spatial and temporal exploitation of growing network connectivity potential generate prerequisities for economies of scale and economies of density for airline business.

Ryanair also achieved the lowest levels of network concentration indices among the analysed airlines what underlines an assumption about deconcentrated network typical for pure (ultra) low cost carriers and almost all airlines with expanding networks (with exception of Aer Lingus) deconcentrated their networks. Gillen in 2006 anticipated: The evolution of networks in today's envi- 
ronment will be based on the choice of business model that airlines make. ${ }^{28}$ Our network analysis did not confirm any distinct demarkation line within the group of airlines analysed with regard to the results of spatial network ratios we used. Even enlarging the 2014 group of analysed airlines by Air Berlin + Niki, Air Baltic and Meridiana Fly which were identified as full service carriers by Klophaus et al.:29 (in the sense of converted ones - a note of the authors) did not clear up the topic. Therefore, we see research aimed at the evolution of airlines networks according to the business models as a perspective issue, mainly taking into account many innovations in passenger airline business models observed on the present. Papers of Mason and Morrison, ${ }^{30}$ Daft and Alberts, ${ }^{31}$ Lohman and Koo ${ }^{32}$ focused on different attributes of business models, network attributes included but the studies still kept the traditional approach distinguishing between low cost carriers and full service network ones.

The approach we used may be useful in several further analytical contexts. As expansion of networks may be achieved through organic growth of airlines and/or through mergers and acquisitions, impact of mergers and acquisition on networks evolution in time could be investigated following the approach we used. Such analysis (together with other quantitative signalls like break-even load factor) could contribute to better comprehension of airlines network behaviour before bancruptcy. Further usefullnes of our approach is foreseen by us when analysing impacts of international aviation markets liberalisation through liberal air service agreements. Due to liberalisation, a new geographical space for network expansion of airlines will be creating and airlines with different network strategies (and different business models) can exploit a new space of liberalised markets differently. According to our anticipation, just synergies between economies generated by spatial connectivity of airline network and economies

28 D. Gillen, 2006. Airline Business Models and Networks: Regulation, Competition and Evolution in Aviation Markets. Review of Network Economics 5/4, 366-385.

29 R. Klophaus et al., 2012. Low cost carriers going hybrid: Evidence from Europe. Journal of Air Transport Management 23, 54-58.

30 J.K. Mason, W.G. Morrison, 2008. Towards a means of consistently comparing airline business models with an application to the 'low cost' airline sector. Research in Transportation Economics 24, 75-84.

31 J. Daft, S. Alberts, 2012. A conceptual framework for measuring airline business model convergence. Working Paper. Department of Business Policy and Logistics, University of Cologne, No. 110.

32 G. Lohmann, KOO, T.T.R., 2013. The airline business model spectrum. Journal of Air Transport Management 31, 7-9. 
generated by temporal connectivity of airline network will play a crucial role in competition of airlines, airlines competing for a new business space.

\section{Bibliography}

Belobaba P. et al., 2009. The Global Airline Industry. Wiltshire: John Wiley \& Sons.

Burghouwt G. - de Wit J., 2003. The Temporal Configuration of European Airlines Networks. www.researchgate.net/profile/Guillaume_Burghouwt/publication/222829757_Temporal_configurations_of_European_airline_networks/links/ 0c96051c05f63b67f6000000.pdf.

Burghouwt G. et al., 2003. The spatial configuration of airline networks in Europe. Journal of Air Transport Management 9, 309-323.

Daft J., Alberts S., 2012. A conceptual framework for measuring airline business model convergence. Working Paper. Department of Business Policy and Logistics, University of Cologne, No. 110.

Dobruszkes F., 2006. An analysis of European low-cost airlines and their networks. Journal of Transport Geography 14, 249-264.

Dobruszkes F., 2013. The geography of European low-cost airline networks: a contemporary analysis. Journal of Transport Geography 28, 75-88.

Dudas G., 2010. Low Cost Airlines in Europe: Network Structure after the Enlargement of the European Union. Geographica Pannonica 14/2, 49-58.

European Commission, 2013. Annual Analysis of the EU Air Transport Market, 2011. http://ec.europa.eu/transport/modes/air/internal_market/observatory_market/doc/ annual-2011-summary.pdf.

Gillen D., 2006. Airline Business Models and Networks: Regulation, Competition and Evolution in Aviation Markets. Review of Network Economics 5/4, 366-385.

Huettinger M., 2006. Air Baltic and SAS - a case study in the European airline industry. Baltic Journal of Management, Vol. 1 Iss: 2, pp. 227-244.

ICAO, 2014. List of LCC based on ICAO definition. www.icao.int/sustainability/Documents/LCC-List.pdf.

Klophaus R. et al., 2012. Low cost carriers going hybrid: Evidence from Europe. Journal of Air Transport Management 23, 54-58.

Lohmann G., KOO, T.T.R., 2013. The airline business model spectrum. Journal of Air Transport Management 31, 7-9.

Mason J.K., Morrison W.G., 2008. Towards a means of consistently comparing airline business models with an application to the 'low cost' airline sector. Research in Transportation Economics 24, 75-84. 
Müller K. et al., 2012. The Construction of a Low Cost Airline Network: Facing competition and exploring new markets. ZEW Discussion Paper No. 11-052. http://ftp.zew. de/pub/zew-docs/dp/dp11052.pdf.

NAIR, S.K.S. et al., 2011. The Analysis of Airline Business Models in the Development of Possible Future Business Options. World Journal of Management 3 No. 1. 48-59.

OECD, 2014. Airline Competition. Background Paper by the Secretariat. DAF/ $\operatorname{COMP}(2014 / 14)$.

Reggiani A. et al., 2011. Connectivity and Concentration in Airline Networks: A Complexity Analysis of Lufthansa's Network. TI 2011-111/3 Tinbergen Institute Discussion Paper.

Reynolds-Ferighan A.J., 2010. Characterisation of airline networks: a North American and European Comparison. Journal of Air Transport Management 16, 109-120.

Scholz A.B., 2011. Spatial Network Configurations of Cargo Airlines. Working Papers in Economics, No 20, Karlsruher Institut für Technologie.

UNCTAD, 2014. Geographical Spread Index. http:/unctad.org/sections/dite_dir/docs/ WIR11_web\%20tab\%2031.pdf.

Vidovic A. et al., 2013. Development of Business Models of Low Cost Airlines. International Journal of Traffic and Transportation Engineering 3 (1), 69-81.

\section{STRATEGIA POLĄCZEŃ NISKOKOSZTOWYCH \\ I HYBRYDOWYCH LINII LOTNICZYCH: \\ CZY RYANAIR JEST WYJĄTKOWY?}

\section{Streszczenie}

Artykuł poświęcony jest analizie strategii połączeń jedenastu europejskich niskokosztowych i hybrydowych linii lotniczych (między 2009 i 2014 rokiem), która koncentruje się na atrybutach przestrzennych (geograficznych). Dwuwymiarowy opis ewolucji połączeń sieci lotniczych zidentyfikował trzy z czterech możliwych przestrzennych strategii połączeń, za którymi podążały linie lotnicze: ekspansję, kurczenie się i kondensację - uwydatniając ekspansję jako strategię dominującą. Ryanair, jako rozwijająca się linia lotnicza, wzmocnił ponadnarodowy charakter swojej sieci (co zostało potwierdzone przez geograficzne rozprzestrzenienie) - jednak na obszarze Europejskiego Obszaru Gospodarczego rozszerzył swoją działalność najmniej spośród rozrastających się linii lotniczych. Wśród porównywanych linii tylko Ryanair zwiększył wykorzystanie potencjału łączności 
sieciowej. Miał też najniższy poziom koncentracji sieci, co potwierdza założenie o zdecentralizowaniu sieci typowym dla tanich przewoźników. Badawcze ustalenia potwierdzają konstatację, że oszczędności osiągane na drodze połączenia przestrzennego linii lotnicznych grają decydującą rolę w konkurowaniu linii lotniczych, jako że ich działalność handlowa jest w zasadzie zdeterminowana przestrzennie.

Słowa kluczowe: linie lotnicze, sieć, strategia, łączność, koncentracja, zasięg geograficzny, korzyści skali 
